\title{
ANALISIS NILAI TAMBAH PELAKU RANTAI PASOK GAMBIR DENGAN METODE HAYAMI TERMODIFIKASI
}

\author{
Hendra Saputra ${ }^{1}$, Novizar Nazir $^{2}$, dan Rina Yenrina ${ }^{2}$ \\ ${ }^{1}$ Institut Teknologi Sumatera, Jalan Terusan Ryacudu, Way Hui, Jati Agung, Lampung Selatan 35365 \\ ${ }^{2}$ Universitas Andalas, Limau Manis, Padang, 25163, Indonesia \\ E-mail: hendra.saputra@tin.itera.ac.id
}

\begin{abstract}
ABSTRAK
Gambir merupakan komoditas unggulan Sumatera Barat, produktivitas rantai pasok gambir saat ini masih memiliki kendala dari tingkat keuntungan yang tidak setara di setiap aliran rantainya. Tujuan penelitian ini adalah mengetahui nilai tambah yang diperoleh di setiap pelaku rantai pasok gambir. Mekanisme rantai pasok gambir diidentifikasi menggunakan metode kualitatif. Penelitian ini dilakukan dengan pendekatan sistem yang didukung dengan metode Hayami termodifikasi untuk menghitung nilai tambah. Pada skala industri kapasitas pabrik pengolahan eksportir gambir $1250 \mathrm{~kg}$ gambir/jam dan tingkat harga jual gambir masyarakat Rp. 45.000/kg, harga Gambir katekin (Produksi eksportir) Rp $189.000 / \mathrm{kg}$ di dapat hasil perbandingan nilai tambah Petani $(11 \%)$ : Pedagang pengumpul $(30 \%)$ : Eksportir lokal (60 \%). Dari total nilai tambah yang dihasilkan sebesar Rp.322.602.481.833 pertahun terlihat perbandingan nilai tambah diantara para pelaku rantai pasok gambir yaitu petani, pedagang pengumpul, dan eksportir lokal dimana petani memperoleh Rp. 20.052/kg, pedagang pengumpul Rp. $55.135 / \mathrm{kg}$ dan eksportir lokal Rp. 110.813/kg. Berdasarkan besaran nilai tambah per kg gambir yang diperoleh disetiap rantai pasok gambir, eksportir lokal menerima bagian pendapatan yang lebih baik dibandingkan dengan petani dan pedagang pengumpul.

Kata kunci-gambir; rantai pasok; nilai tambah
\end{abstract}

\section{PENDAHULUAN}

Gambir merupakan resin yang diekstrak dari daun dan cabang-cabang muda tanaman gambir (Uncaria gambir Roxb.), dikristalkan dan diperdagangkan dalam bentuk kubus atau blok kecil (Ridsdale, 2007). Sentra perkebunan gambir di Indonesia adalah Aceh, Sumatera Barat, Sumatera Utara, Riau, Bangka Belitung, Sumatera Selatan, dan Papua (Amos et al., 2005). Sumatera Barat, Sumatera Utara, Riau, dan Sumatera Selatan merupakan propinsi sentra produksi gambir Sumatera. Diantara keempat sentra produksi gambir tersebut, Propinsi Sumatera Barat merupakan sentra produksi gambir terbesar yang memasok sekitar 90\% dari total produksi gambir nasional (Gumbira-Sa'id et al, 2009).

Rantai pasok gambir memiliki berbagai macam alternatif pilihan dalam menyalurkan gambir. Untuk itu dalam penelitian ini, diperlukan identifikasi saluran pemasaran yang bertujuan untuk melihat perilaku setiap lembaga pemasaran dalam memilih saluran pemasaran untuk memamasarkan gambir. Perbedaan bentuk pemasaran ini bisa dipengaruhi oleh karakteristik pemasaran di daerah serta berdasarkan jenis gambir serta harga gambir.

Nilai tambah adalah salah satu bentuk ukuran kinerja perusahaan dan rantai pasok. Dalam suatu rantai pasok pemasaran, setiap pelaku melaksanakan fungsi tertentu yang memberikan nilai tambah, dengan harapan akan mendapat imbalan yang proporsional sesuai dengan mutu jasa atau fungsi yang diberikan. Kekuasaan dalam suatu mata rantai apabila tidak berbagi secara rata diantara pelaku tidak akan terjadi distribusi nilai tambah yang seimbang didalam rantai pasok tersebut. Konsentrasi kekuasaan pada suatu pelaku tertentu berpangkal dari penguasaan akses pelaku terhadap informasi pasar, sehingga menghasilkan perbedaan dalam marjin pendapatan pada para pelaku rantai pasok itu (Bunte, 2006). Distribusi nilai tambah atau keuntungan sepanjang rantai suatu pasok haruslah adil dan disepakati semua rantai pasok untuk menjaga kerjasama dan keberlangsungannya, oleh karena itu perlu diketahui porsi nilai tambah yang di peroleh masing-masing pelaku rantai pasok gambir dari usaha yang dilakukan. 


\section{METODE PENELITIAN}

\section{A. Waktu dan Tempat Penelitian}

Kegiatan pengumpulan data dan informasi terkait rantai pasok gambir dilakukan bulan April sampai Juni 2017 di Kabupaten Lima Puluh Kota (Kapur IX, Pangkalan dan Bukit Barisan) dan Kabupaten Pesisir Selatan (Koto XI Tarusan, Sutera dan Batang Kapas) dan Kota Padang, Sumatera Barat.

\section{B. Identifikasi Rantai Pasok Gambir}

Identifikasi rantai pasok gambir dilakukan dengan menggunakan metode deksriptif-kualitatif dengan pendapat pakar praktisi dan akademisi, observasi lapangan serta studi pustaka sebagai data pendukung. Kerangka analisis manajemen rantai pasok gambir dapat dilihat pada Gambar 1. Analisis rantai pasok gambir dilakukan dengan mengidentifikasi empat elemen dasar rantai pasok (Vorst, 2006). Empat elemen tersebut dapat mendeskripsikan rantai pasok secara terstruktur, elemen-elemen tersebut adalah :

1) Struktur rantai menjelaskan ruang lingkup rantai dan peran anggota rantai pasok serta kesepakatankesepakatan yang membentuk rantai pasok.

2) Proses bisnis rantai merupakan serangkaian aktivitas bisnis terstruktur dan terukur untuk menghasilkan output tertentu bagi konsumen.

3) Manajemen jaringan dan rantai menggambarkan koordinasi untuk melaksanakan proses dalam rantai pasok oleh anggota.

4) Sumberdaya rantai digunakan untuk menghasilkan produk dan mengirimkan ke konsumen.

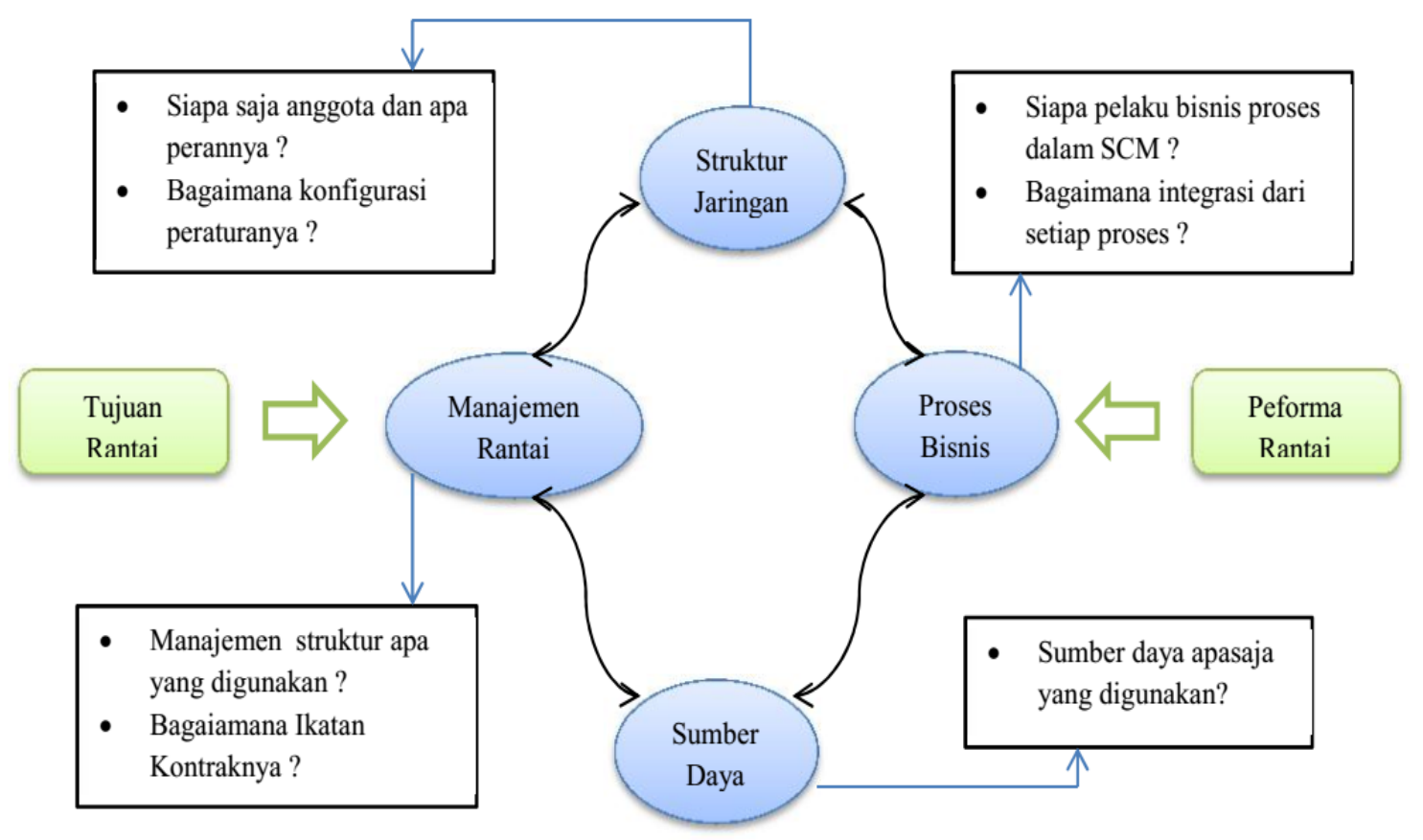

Gambar 1. Kerangka Analisis Rantai Pasok (Vorst, 2006)

\section{Analisis Nilai Tambah Rantai Pasok Gambir}

Sumber data terkait nilai tambah berdasarkan perhitungan Hayami didapatkan melalui wawancara kepada petani, pedagang pengumpul dan eksportir lokal dengan bantuan kuisioner yang telah disusun berdasarkan kebutuhan data dan informasi. Perhitungan menggunakan metode Hayami modifikasi dikembangkan oleh Hidayat (2012), keuntungan analisis ini dapat dihitung nilai tambah selama 1 tahun produksi dan meilhat porsi nilai tambah per rantai pasok setiap bulannya. Pada Tabel 1 disajikan template metode Hayami Termodifikasi. 
Tabel 1. Template perhitungan nilai tambah Metode Hayami di Modifikasi (Hidayat, 2012)

\begin{tabular}{|c|c|c|c|}
\hline & Variabel & Satuan & Nilai \\
\hline \multicolumn{4}{|c|}{ Interaksi rantai pasok gambir } \\
\hline 1 & Harga beli bahan & $\mathrm{Rp} / \mathrm{kg}$ & (1) \\
\hline 2 & Harga jual produk & $\mathrm{Rp} / \mathrm{kg}$ & (2) \\
\hline 3 & Total nilai tambah per $\mathrm{kg}$ output & $\mathrm{Rp} / \mathrm{kg}$ & $(3)=(2$ terakhir $)-(1)$ \\
\hline \multicolumn{4}{|c|}{ I. Input, Output dan Harga } \\
\hline \multirow[t]{2}{*}{4} & a. Output (Volume Penjualan) & $\mathrm{Kg}$ & (4a) \\
\hline & b. Input (nilai penjualan) & $\mathrm{Rp}$ & (4b) \\
\hline 5 & Bahan Baku Pokok & $\mathrm{Rp}$ & (5) \\
\hline 6 & Tenaga Kerja Langsung & $\mathrm{HOK}$ & (6) \\
\hline 7 & Faktor konversi & & $(7)=(4 b) /(5)$ \\
\hline 8 & Koefesien tenaga kerja langsung & $\mathrm{Rp} / \mathrm{HOK}$ & $(8)=(4 b) /(6)$ \\
\hline 9 & Upah tenaga kerja langsung & $\mathrm{Rp}$ & (9) \\
\hline \multicolumn{4}{|c|}{ II. Penerimaan dan Nilai Tambah } \\
\hline & a. Biaya input lain (Produksi) & $\mathrm{Rp}$. & (10a) \\
\hline & b. Biaya input lain (Operasional) & Rp. & $(10 b)$ \\
\hline \multirow[t]{2}{*}{11} & a. Nilai Tambah & $\mathrm{Rp}$. & $(11 a)=4 b-(5+10 a+10 b)$ \\
\hline & b. Rasio Nilai Tambah & $\%$ & $(11 b)=(11 a) /(4 b)$ \\
\hline \multicolumn{4}{|c|}{ III. Balas Jasa Pemilik Faktor Produksi } \\
\hline & Margin & $\mathrm{Rp}$. & $(12)=(4 b)-5$ \\
\hline & a. Sumbangan biaya iput lain & $\%$ & $(12 a)=(10 a)+(10 b) /(12) * 100 \%$ \\
\hline & b. Keuntungan perusahaan & $\%$ & $(12 b)=(11 a) /(12)^{*} 100 \%$ \\
\hline \multicolumn{4}{|c|}{ IV. Porsi Nilai Tambah per Kg Produk } \\
\hline \multirow[t]{3}{*}{13} & a. Dalam nilai uang & Rp. & $(13 a)=(11 a) /(\Sigma 11 a) *(3)$ \\
\hline & b. Dalam persentasi & & $(13 b)=(13 a) /(3) * 100 \%$ \\
\hline & c. Nilai tambah per petani & $\mathrm{Rp} / \mathrm{kg}$ & \\
\hline
\end{tabular}

Metode hayami modifikasi merupakan formulasi perhitungan menggunakan tabel worksheet microsoft excel untuk mendapatkan nilai tambah para stakeholder, nilai tambah total rantai pasok, dan dapat dihitung perbandingan antara nilai-nilai tambah tersebut. Perhitungan menggunakan metode hayami bertujuan untuk membandingkan bobot nilai tambah yang diterima oleh setiap pelaku rantai pasok gambir.

\section{HASIL DAN PEMBAHASAN}

\section{A. Rantai Pasok Gambir Sumatera Barat}

Saluran pemasaran gambir di Kabupaten Lima Puluh Kota terdapat pada lima rantai pasok gambir yaitu Saluran 1: Petani - Pedagang Pengumpul - Eksportir Lokal - Konsumen Luar, Saluran 2: Petani - Penyalur - Pedagang Besar - Eksportir Lokal - Konsumen Luar Negeri, Saluran 3 : Petani Pedagang Besar - Eksportir Lokal - Konsumen Luar Negeri, Saluran 4 : Petani - Pedagang pengumpul - Pedagang Besar - Eksportir Lokal - Konsumen Luar Negeri dan Saluran 5 : Petani - Pedagang Besar - Eksportir Luar Provinsi/Pedagang Besar di Pulau Jawa - Disrtibutor - Konsumen luar/dalam Negeri.

Kabupaten Pesisir Selatan dapat digeneralisasikan saluran pemasaran di rantai pasok gambir karena hanya terdapat satu jenis saluran pemasaran, adapun bentuk saluran pemasaran di rantai pasok gambir di Kabupaten Pesisir Selatan sama hal nya dengan saluran 1 di rantai pasok Kabupaten lima puluh kota yaitu Petani, pedagang pengumpul, eksportir lokal dan konsumen luar negeri, berikut rantai pasok gambir di Sumatera Barat. Saluran pemasaran gambir di Sumatera Barat dapat dilihat pada Gambar 2. 


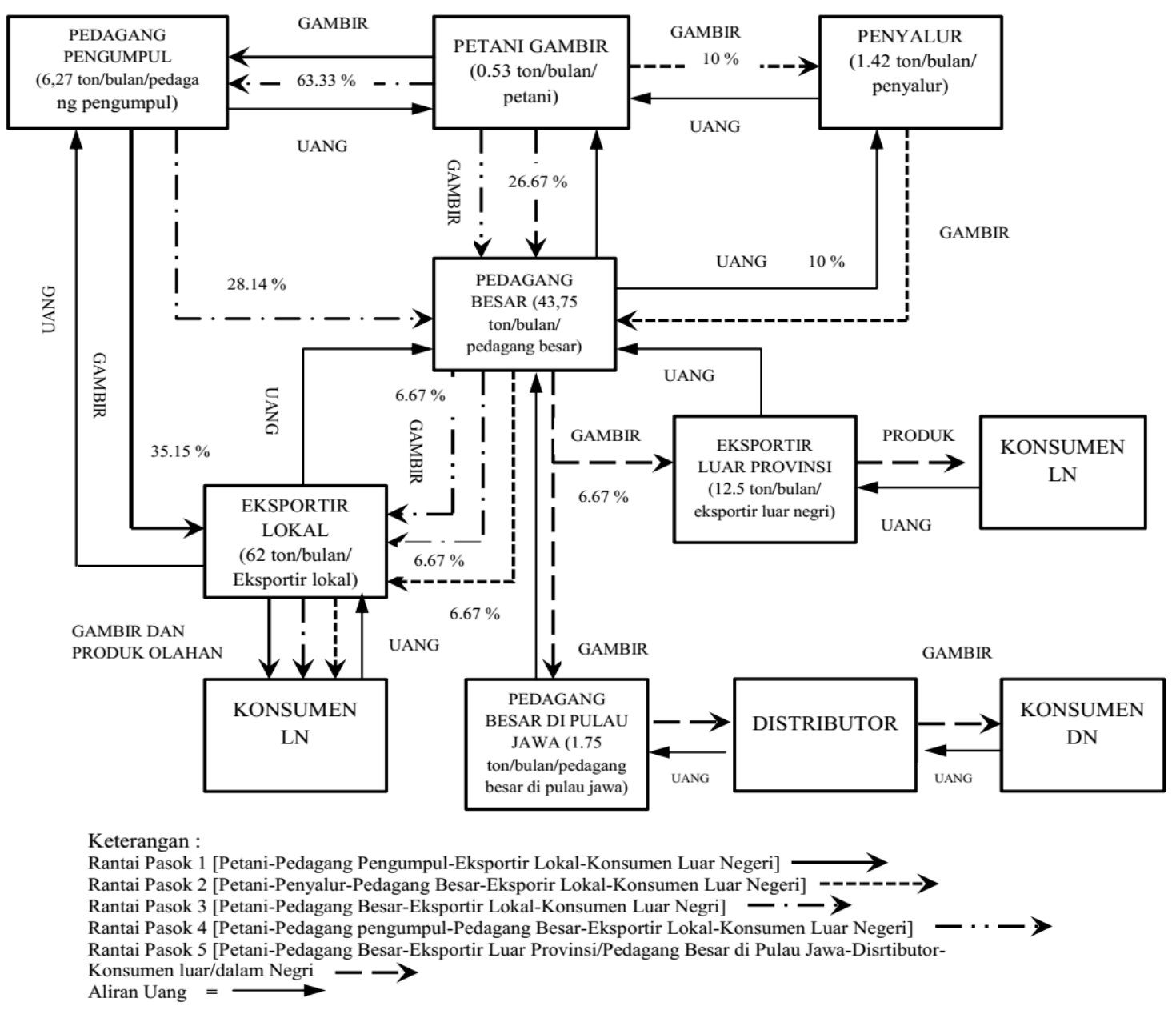

Gambar 2. Saluran Rantai Pasok Gambir Sumatera Barat

Menurut Amri (2015) rantai pasok gambir di Sumatera Barat terdapat 4 bentuk rantai pasok gambir, pada penelitian ini di temukan rantai pasok gambir yaitu sebagai penyalur yang merupakan perpanjangan tangan dari pedagang besar dalam rantai pasok gambir. Pemilihan rantai pasok gambir untuk kesetaraan nilai tambah pada rantai pasok gambir ditentukan dari keseragaman rantai pasok gambir pada masing-masing wilayah sentra produksi gambir dan persentase pemilihan saluran pemasaran gambir. Menurut Hidayat (2012) perhitungan nilai tambah menggunakan metode Hayami termodifikasi digunakan untuk satu saluran pemasaran dengan melihat kapasitas produksi pabrik/tahun.

Rantai pasok gambir yang dilakukan analisis nilai tambah pada penelitian ini yaitu saluran 1 pemasaran gambir dimulai dari petani, pedagang pengumpul, eksportir lokal dan konsumen luar negri yang memiliki persentase penjualan tertinggi yaitu $(63,33 \%)$ petani memilih untuk menjual ke pedagang pengumpul, selanjutnya pedagang pengumpul sebanyak $35,85 \%$ memilih menjual ke eksportir lokal. Pada penelitian ini saluran 1 memiliki kesamaan di Kabupaten Lima Puluh Kota dan Kabupaten Pesisir Selatan. Berdasarkan analisis lembaga pemasaran gambir menurut Nasution (2015) persentase penjualan ke pedagang pengumpul mencapai $58,54 \%$ dan dilanjutkan ke eksportir lokal $27,42 \%$.

\section{B. Hasil Perhitungan Nilai Tambah}

Perhitungan nilai tambah dengan beberapa nilai variabel harga komoditas, yaitu harga daun gambir, harga gambir, gambir katekin (gambir yang siap ekspor). Kemudian dilakukan juga perhitungan nilai tambah dengan perubahan pada variabel investasi dan biaya para pelaku rantai pasok gambir. Hasil perhitungan nilai tampak yang di peroleh setiap pelaku gambir selama 1 tahun dapat dilihat pada Tabel 2. 


\begin{tabular}{|c|c|c|c|c|c|c|}
\hline No & Variable & Satuan & Petani & Pedagang & Eksportir & Konsumen \\
\hline \multicolumn{7}{|c|}{ Interaksi Rantai pasok gambir } \\
\hline 1 & Harga beli bahan & $\mathrm{Rp} / \mathrm{kg}$ & 3,000 & 45,000 & 64,000 & 189,000 \\
\hline \multirow[t]{2}{*}{2} & Harga jual produk & $\mathrm{Rp} / \mathrm{kg}$ & 45,000 & 82,000 & & \\
\hline & Produk I & & & & 189,000 & \\
\hline 3 & $\begin{array}{l}\text { Total nilai tambah per } \mathrm{kg} \\
\text { output }\end{array}$ & $\mathrm{Rp} / \mathrm{kg}$ & & & 186,000 & \\
\hline \multicolumn{7}{|c|}{ I. Output, Input, dan Harga } \\
\hline \multirow[t]{2}{*}{4} & a. Output (volume penjualan) & $\mathrm{Kg}$ & $3,120,000$ & $3,120,000$ & $2,433,600$ & \\
\hline & b. Output (Nilai Penjualan) & $\mathrm{Rp}$ & $140,400,000,000$ & $255,840,000,000$ & $459,950,400,000$ & \\
\hline 5 & Bahan Baku Pokok & $\mathrm{Rp}$ & $65,520,000,000$ & $140,400,000,000$ & $255,840,000,000$ & \\
\hline 6 & Tenaga Kerja Langsung & HOK & 180 & 288 & 312 & \\
\hline 7 & Faktor Konversi & & 2 & 2 & 2 & \\
\hline 8 & Koefisien T. Kerja Langsung & $\mathrm{Rp} / \mathrm{HOK}$ & $780,000,000$ & $1,522,857,143$ & $1,474,200,000$ & \\
\hline 9 & Upah Tenaga Kerja Langsung & $\mathrm{Rp}$ & $70,200,000,000$ & $1,872,000,000$ & $835,200,000$ & \\
\hline \multicolumn{7}{|c|}{ II. Penerimaan dan Nilai Tambah } \\
\hline \multirow[t]{2}{*}{10} & a. Biaya Input lain (Produksi) & $\mathrm{Rp}$ & $36,980,991,667$ & $14,163,760,000$ & $3,405,202,500$ & \\
\hline & $\begin{array}{l}\text { b. Biaya Input lain } \\
\text { (Operasional) }\end{array}$ & $\mathrm{Rp}$ & $3,120,000,000$ & $5,648,500,000$ & $8,509,464,000$ & \\
\hline \multirow[t]{2}{*}{11} & a. Nilai Tambah & $\mathrm{Rp}$ & $34,779,008,333$ & $95,627,740,000$ & $192,195,733,500$ & $322,602,481,833$ \\
\hline & b. Rasio Nilai tambah & $\%$ & 25 & 37 & 42 & \\
\hline \multicolumn{7}{|c|}{ III. Balas Jasa Pemilik faktor Produksi } \\
\hline \multirow[t]{3}{*}{12} & Margin & $\mathrm{Rp}$ & $74,880,000,000$ & $115,440,000,000$ & $204,110,400,000$ & \\
\hline & $\begin{array}{l}\text { a. Sumbangan Biaya Input } \\
\text { lain }\end{array}$ & $\%$ & 54 & 17 & 6 & \\
\hline & b. Keuntungan perusahaan & $\%$ & 46 & 83 & 94 & \\
\hline \multicolumn{7}{|c|}{ IV. Porsi Nilai tambah per kg produk } \\
\hline \multirow[t]{3}{*}{13} & a. Dalam nilai uang & $\mathrm{Rp}$ & 20,052 & 55,135 & 110,813 & 186,000 \\
\hline & b. Dalam persentasi & $\%$ & 11 & 30 & 60 & \\
\hline & c. Nilai tambah per petani & $\mathrm{Rp} / \mathrm{bln}$ & $4,458,847$ & & & \\
\hline
\end{tabular}

Pada skala industri kapasitas pabrik pengolahan eksportir gambir $1250 \mathrm{~kg}$ gambir/jam dibutuhkan sebanyak $3.120 .000 \mathrm{~kg}$ gambir per tahun, yang dihasilkan dari kebun petani gambir seluas 650 ha. Dengan asumsi setiap petani memiliki 1 hektar kebun gambir maka diperlukan 650 orang petani. Nilai tambah (NT) rantai pasok pada baris 13.a memperhatikan faktor konversi bahan menjadi produk akhir. Hal ini adalah untuk menjaga kesetaraan nilai. Untuk setiap pelaku NT dihitung dengan mengetahui selisih \{(harga produk-harga bahan) $\mathrm{x}$ volume bahan $\mathrm{x}$ faktor konversi $\}$. Pada tingkat harga jual gambir masyarakat Rp. 45.000/kg, harga Gambir katekin Rp 189.000/kg di dapat hasil perbandingan nilai tambah Petani (11\%) : Pedagang pengumpul (30\%) : Eksportir lokal (60\%). Nilai tambah tertinggi adalah eksportir lokal sebesar Rp. 192.195.733.500 selanjutnya pedagang pengumpul Rp. 95.627.740.000 dan petani Rp.34.779.008.33 untuk satu tahun. nilai tambah untuk setiap petani Rp/bulan. 4.458.847. Dari total nilai tambah yang dihasilkan sebesar Rp.322.602.481.833 terlihat perbandingan nilai tambah diantara para pelaku rantai pasok gambir yaitu petani, pedagang pengumpul, dan eksportir lokal dimana petani memperoleh Rp. 20.052/kg, pedagang pengumpul Rp. 55.135/kg dan eksportir lokal Rp. 110.813/kg.

Berdasarkan besaran nilai tambah per kg gambir yang diperoleh disetiap rantai pasok gambir, eksportir lokal dan pedagang pengumpul menerima bagian pendapatan yang lebih baik dibandingkan dengan petani. Metode Hayami termodifikasi yang dikembangkan oleh Hidayat (2012), dapat mengetahui interaksi disetiap rantai pasok sehingga menghitung keuntungan yang diperoleh oleh rantai pasok dari Rp/kg produk, hal ini memperlihatkan peran petani dalam memasok kebutuhan eksportir lokal dalam memproduksi gambir dalam kurun waktu satu tahun serta keuntungan yang diperoleh per petani Rp/bulan.

Hasil perhitungan didapatkan pembagian nilai tambah tidak merata sepanjang rantai pasok gambir. Eksportir lokal dan pedagang pengumpul menghasilkan nilai tambah yang lebih baik dibandingkan dengan petani. Kondisi ini terjadi karena mekanisme pasar disepanjang rantai pasok yang menekan petani, kemudian juga dari biaya-biaya yang diberikan untuk produksi gambir. Menurut Hidayat (2012) penyebab-penyebab utama dari sebaran nilai tambah tidak merata adalah mekanisme pasar dan biaya-biaya. Mekanisme pasar adalah penentuan tingkat harga jual produk, besarnya volume 
pasar, interaksi antara pasokan dan permintaan, struktur pasar (oligopoly atau monopsoni atau lainnya). Oleh karena itu diperlukan penyeimbangan pembagian nilai tambah sehingga menjamin keberlangsungan manajemen rantai pasok gambir.

\section{KESIMPULAN}

Pada skala industri kapasitas pabrik pengolahan eksportir gambir $1250 \mathrm{~kg}$ gambir/jam dan tingkat harga jual gambir masyarakat Rp. 45.000/kg, harga Gambir katekin Rp. 189.000/kg di dapat hasil perbandingan nilai tambah Petani (11\%) : Pedagang pengumpul (30\%) : Eksportir lokal (60\%). Nilai tambah tertinggi adalah eksportir lokal sebesar Rp. 192.195.733.500 selanjutnya pedagang pengumpul Rp. 95.627.740.000 dan petani Rp.34.779.008.33 untuk satu tahun. nilai tambah untuk setiap petani $\mathrm{Rp} /$ bulan. 4.458.847. Dari total nilai tambah yang dihasilkan sebesar Rp.322.602.481.833 terlihat perbandingan nilai tambah diantara para pelaku rantai pasok gambir yaitu petani, pedagang pengumpul, dan eksportir lokal dimana petani memperoleh Rp. 20.052/kg, pedagang pengumpul Rp. $55.135 / \mathrm{kg}$ dan eksportir lokal Rp. 110.813/kg. Berdasarkan besaran nilai tambah per kg gambir yang diperoleh disetiap rantai pasok gambir, eksportir lokal menerima bagian pendapatan yang lebih baik dibandingkan dengan petani dan pedagang pengumpul.

\section{DAFTAR PUSTAKA}

Amos, I., Zainuddin, B, Triputranto, S. Rusmandana, dan Ngudiwaluyo. 2005. Teknologi Pasca Panen Gambir. BPPT Press, Jakarta.

Amri, N.A. 2015. Analisis dan arahan pengembangan komoditas Gambir (Uncaria gambier roxb.) Dalam rangka Pengembangan ekonomi wilayah Di kabupaten limapuluh kota. Tesis. IPB

Bunte F. 2006. Pricing And Performance In Agri-Food Supply Chains First Edition; 37-45. LEI, Wageningen University and Research Centre. Wageningen.

Gumbira-Sa'id, E. K. Syamsu, E. Mardliyati, A. H. Brotoadie, dan N. A. Evalia. 2009. Perbaikan Rekayasa Proses, Pengembangan Produk dan Peningkatan Mutu Gambir Ekspor Indonesia: Pendalaman Studi Kasus di Kabupaten Lima puluh Kota, Propinsi Sumatra Barat. Laporan penelitian Hibah Unggulan Strategis Nasional. Institut Pertanian Bogor.

Hidayat, Syarif. 2012. Model Penyeimbangan Nilai Tambah Berdasarkan Tingkat Resiko Pada Rantai Pasok Minyak Sawit [Penelitian Disertasi] Institut Pertanian Bogor

Ridsdale, C.E. 1993. Uncaria gambir (Hunter) Roxb. Di dalam R.H.M.J. Lemmens, N. WulijarniSoetjipto (eds.). PROSEA-Plant Resources of South-East Asia No.3: Dye and TanninProducing Plants. Pudoc Wageningen, The Netherlands.

Vorst Vd. 2006. Performance Measurement in Agrifood Supply Chain Networks: an Overview. In: Quantifying the Agri-food Supply Chain. Wegenigen (NL): Logistic and Operation Research Group. 